\title{
Characterization of Cyanobacterial Isolates from Rann of Kutch for Salinity Tolerance
}

\author{
Yattapu Prasad Reddy*, Ravindra Kumar Yadav and G. Abraham
}

Centre for Conservation and Utilization of BGA, ICAR-Indian Agricultural Research Institute, New Delhi-110012, India

*Corresponding author

\section{A B S T R A C T}

\begin{tabular}{|l|}
\hline Ke y w or d s \\
$\begin{array}{l}\text { Cyanobacteria, Extreme } \\
\text { environment, 16 S r DNA }\end{array}$ \\
\hline Article Info \\
\hline Accepted: \\
06 May 2018 \\
Available Online: \\
10 June 2018 \\
\hline
\end{tabular}

Isolation and characterization of cyanobacteria from extreme environment is important in identifying novel molecules and understanding the mechanisms underlying the tolerance. Therefore in the present study an attempt was made to isolate, identify and characterize cyanobacteria from Runn of Kutch experiencing high levels of salinity. On the basis of microscopic, morphological and cultural characteristics the identified cyanobacterial strains included Anabaena, Nostoc, Westielliopsis, Phormidium and Synechocystis. Further analysis on the basis of 16S rDNA sequence and BLAST analysis confirmed their identity. Growth, cellular constituents and parameters of nitrogen assimilation in these strains were studied and showed significant differences. The present investigation helped in the identification of cyanobacterial strains tolerant to high salt concentration will help in selecting appropriate strains as bio-fertilizer.

\section{Introduction}

Cyanobacteria occupy one of the largest and diverse groups of photosynthetic organisms having a unique distribution pattern. They have been found to colonize successfully in several diverse types of ecosystems. The origin of cyanobacteria dates back to the PreCambrian times and this long evolutionary history holds the key to their competitive success to thrive in a wide range of environment. They have the ability to tolerate high temperature, UV desiccation, water and saline stress (Gröniger and Hader, 2000; Whitton and Potts, 2000; Herrero and Flores, 2008). These organisms are important because they made the atmosphere oxygenic and allowed other organisms to develop. The cyanobacteria are the simplest photosynthetic organisms and are the only prokaryotic organisms to carry out a higher plant type oxygen evolving photosynthesis. Their chloroplasts are remarkably similar to higher plant chloroplasts in structure and function. They are important as primary producers in soil, fresh water and marine environments.

Since, time immemorial the cyanobacteria played key role in maintaining the sustainability of ecosystems and improved soil fertility and crop production. Further advancement in the field of microbiology and biotechnology helped in the exploration of cyanobacteria for industrially important and 
valuable products from them. The cyanobacteria are also rich sources of industrially important compounds. Burja et al., (2001) reported a variety of cyanobacterial products from diverse cyanobacteria. In this context exploration of newer habitats, especially the extreme ones is important from a biotechnological prospective. Hence, search for these organisms from extreme environments would be an important strategy to isolate and identify potential organisms for exploitation. The cyanobacterial isolates from extreme habitats may constitute an important component of the vast an unexplored biological potential. The cyanobacteria are able to survive not very high salt concentrations prevailing in diverse hyper saline environments. Oren, (2000) reported that cyanobacteria from extreme environment can contribute significantly to the productivity of such environments. However, there have been very few reports on the cyanobacteria from extreme environment such as Runn of Kutch till date.

\section{Materials and Methods}

Soil samples were collected randomly from five different sites from the Runn of Kutch region of Western Gujarat during June, 2011. These soil samples were used to isolate cyanobacterial strains following standard enrichment culture techniques (Stanier et al., 1971). BG-11 medium (+N for non heterocystous and $-\mathrm{N}$ for heterocystous strains) was used for the isolation procedure. The medium used for the isolation was made saline by the addition of sodium chloride at a concentration of $1-5 \%$ and the $\mathrm{pH}$ was adjusted to 8.0. The isolated and identified cultures were maintained in the culture room having light intensity of $52-55 \mu \mathrm{mol}$ photon $/ \mathrm{m}^{2} / \mathrm{S}, 16 / 8$ light and dark period and $28 \pm .2{ }^{\circ} \mathrm{C}$ temperature. Strains were examined microscopically and the morphological characters were compared according to
Desikachary (Desikachary, 1959). For molecular identification, the technique $16 \mathrm{~S} \mathrm{r}$ DNA gene sequencing was used for the identification of cyanobacterial strains. DNA extraction was carried out using DNeasy Tissue Kit and by following the Manufacturer's Protocol (Genetics, USA). Amplification of 16S rDNA gene fragment was done according to Weisburg et al., (1991) and Lyra et al., (1997). The amplified PCR products were electrophoresed, stained and visualized. The amplified product was sequenced partially. The $16 \mathrm{~S}$ partial gene sequence was subjected to search for highly similar sequence using mega blast and sequences with the highest similarity indicated by BLAST were identified.

Exponentially growing $\left(15^{\text {th }}\right.$ day of incubation) cultures were used for the determination of growth and other physiological variables. The dry weight determination was done according to (Sorokin, 1973). Chlorophyll was determined by the protocol given by (McKinney, 1941) and the carotenoids were estimated according to (Jensen, 1978). Freezing thawing protocol was used for the study of phycobiliproteins (Bennett and Bogorad, 1973). Total protein was estimated by the method of (Lowry et al., 1951). Total carbohydrates were estimated by the method of (Spiro, 1966). The activity of nitrate reductase enzyme was estimated according to (Herrero et al., 1981) and the enzyme activity is expressed as $\mu$ mol $\mathrm{NO}_{2}$ formed per $\mathrm{mg}$ protein by using standard curve of nitrate. Activity of glutamine synthetatse was estimated according to (Shapiro and Stadtman, 1970). Determination of nitrogenase activity was performed by acetylene reduction assay of (Stewart et al., 1968). The results were analyzed by using the statistical package SPSS 10.0. Duncan's multiple range test (DMRT) was employed to compare the mean performances of different treatments for the parameters used in the 
study. The rankings have been denoted by superscripts in appropriate tables.

\section{Results and Discussion}

The morphological attributes of the cyanobacterial isolates from Rann of Kutch identified on the basis of cultural parameters and microscopic observations is shown (Table 1 and 2). Cyanobacterial forms identified on the basis of morphology belong to Anabaena, Nostoc, Phormidium and Westiellopsis. The cyanobacterial strains of Anabaena sp., Nostoc sp., Phormidium and Westiellopsis sp. (YPR4, YPR-6, YPR-8 and YPR-10) grew well at $1 \% \mathrm{NaCl}$. However, at $2 \% \mathrm{NaCl}$, strains of Westiellopsis (YPR-5) were recorded. The strains found to grow at 3\% salinity consisted of Phormidium sp., Anabaena sp. and Nostoc sp (YPR-1, YPR-2, YPR-3, YPR-7 and YPR9). 16S rDNA gene sequencing was used for the identification of cyanobacterial isolates. The extracted and quantified DNA from cyanobacterial isolates was subjected to $16 \mathrm{~S}$ rDNA gene amplification with the primers FD1 and RP2 (Plate 1). Single amplified product of $1500 \mathrm{bp}$ for 16S rDNA was observed in the all the strains examined (Plate 2 ). The amplified product was used for sequence analysis and the BLAST analysis established the homology in terms of \% similarity (Table 3). The cyanobacterial strains of Synechocystis, Phormidium, Anabaena, Nostoc and Westiellopsis showed close similarity with Synechocystis sp (98\%), Phormidium inundatum (98\%), Phormidium priestleyiANT.LACV5.1 (99\%), Anabaena bergii 09-02 (99\%), Anabaena oryzae (97\%), Nostoc elgonense TH3S05 (97\%), Nostoc commune VB516200 (99\%), Nostoc punctiforme (99\%), Westiellopsis prolifica (99\%), Westiellopsis sp. 1590-2 (97\%) respectively.

These strains have been subsequently analyzed for growth and physiological parameters. The growth (dry weight) of these cyanobacterial isolates showed significant variation amongst them (Table 4). Chlorophyll ranged between 0.010 to $2.22 \mu \mathrm{g} / \mathrm{ml}$. YPR-2 showed maximum chlorophyll content whereas YPR-10 recorded the minimum chlorophyll content.

Table 5 shows the phycocyanin, phycoerythrin, allophycocyanin and total phycobiliprotein content of cyanobacterial isolates. Highest phycobiliprotein content was observed in YPR 9 and lowest was observed in YPR-4 Allophycocyanin, phycocyanin and phycoerythrin were highest in YPR-9.

Lowest phycocyanin and phycoerythrin contents were recorded in recorded in YPR-4 whereas lowest allophycocyanin content was recorded in YPR- 6. The range recorded for phycocyanin was to be in the range of 8.05 to $1.003 \mu \mathrm{g} / \mathrm{ml}$ and allophycocyanin content varied in the range of 0.0237 to $0.284 \mu \mathrm{g} / \mathrm{ml}$. The phycoerythrin content showed variation in the range of 0.24 to $1.93 \mu \mathrm{g} / \mathrm{ml}$. However, highest and lowest carotenoid content was observed in YPR-2 and YPR-6, respectively. Carotenoids ranged between 0.22 and 5.82 $\mu \mathrm{g} / \mathrm{ml}$.

The enzymes of nitrogen assimilation were studied in the isolates (Table 6). The nitrate reductase enzyme activity was observed among the strains and the activity ranged between 5.21 to $94.91 \mu$ moles $\mathrm{NO}_{2}$ formed per mg protein. Maximum level of nitrate reductase activity was shown by YPR-4 and lowest activity was observed in YPR-8. Activity of glutamine synthetatse varied in the range of 107.372 to $232.41 \mathrm{n} \mathrm{mol} \gamma_{\text {-glutamyl }}$ hydroxamate formed $\mathrm{min}^{-1} \mathrm{mg}$ protein ${ }^{-1}$. Similarly the strain YPR-10 showed higher levels of GS activity as compared to YPR-2 which showed a low level of activity. Acetylene reduction activity was performed among the heterocystous isolates. 
Table.1 List of cyanobacterial isolates and growth from Rann of Kutch

\begin{tabular}{|c|c|c|c|}
\hline Sl. No. & $\begin{array}{c}\text { Salt concentration } \\
(\%)\end{array}$ & Strain & Taxonomic group \\
\hline 1 & 3 & YPR-1 & Anabaena sp. \\
\hline 2 & 3 & YPR-2 & Anabaena sp. \\
\hline 3 & 3 & YPR-3 & Phormidiumsp. \\
\hline 4 & 1 & YPR-4 & Westiellopsissp. \\
\hline 5 & 2 & YPR-5 & Westiellopsissp. \\
\hline 6 & 1 & YPR-6 & Synechocystissp. \\
\hline 7 & 3 & YPR-7 & Anabaena sp. \\
\hline 8 & 1 & YPR-8 & Phormidiumsp. \\
\hline 9 & 3 & YPR-9 & Nostocsp. \\
\hline 10 & 1 & YPR-10 & Nostocsp. \\
\hline
\end{tabular}

Table.2 Cultural characteristics of the cyanobacterial isolates from Rann of Kutch

\begin{tabular}{|c|c|c|c|c|c|c|}
\hline \multirow{3}{*}{$\begin{array}{l}\text { Sl. } \\
\text { No. }\end{array}$} & \multirow{3}{*}{ Taxonomic } & \multirow{3}{*}{$\begin{array}{l}\text { Designat } \\
\text { ion }\end{array}$} & \multicolumn{4}{|c|}{ Cultural charecteristics } \\
\hline & & & \multirow{2}{*}{$\begin{array}{l}\text { Life } \\
\text { form }\end{array}$} & \multirow[t]{2}{*}{ Colour } & \multicolumn{2}{|c|}{ Pattern of growth } \\
\hline & & & & & Liquid & $\begin{array}{c}\text { Solid } \\
\text { medium }\end{array}$ \\
\hline 1 & Anabaena sp. & YPR-1 & Benthic & $\begin{array}{l}\text { Light } \\
\text { Green }\end{array}$ & Uniform & Mucilaginous, \\
\hline 2 & Anabaena sp. & YPR-2 & Benthic & $\begin{array}{l}\text { Dark } \\
\text { Green }\end{array}$ & Spreading & Spreading \\
\hline 3 & Phormidiumsp. & YPR-3 & Benthic & $\begin{array}{l}\text { Blue } \\
\text { Green }\end{array}$ & Spreading & Spreading \\
\hline 4 & Westiellopsissp. & YPR-4 & Benthic & $\begin{array}{l}\text { Dark } \\
\text { Green }\end{array}$ & Uniform & Bead like \\
\hline 5 & Westiellopsissp. & YPR-5 & Benthic & $\begin{array}{l}\text { Dark } \\
\text { Green }\end{array}$ & Spreading & Spreading \\
\hline 6 & Synechocystissp. & YPR-6 & Benthic & $\begin{array}{l}\text { Dark } \\
\text { Green }\end{array}$ & Uniform & Bead like \\
\hline 7 & Anabaena sp. & YPR-7 & Benthic & $\begin{array}{l}\text { Light } \\
\text { green }\end{array}$ & Floccose & Mucilaginous, \\
\hline 8 & Phormidiumsp. & YPR-8 & Benthic & $\begin{array}{l}\text { Blue } \\
\text { Green }\end{array}$ & Spreading & Spreading \\
\hline 9 & Nostocsp. & YPR-9 & $\begin{array}{l}\text { Plankto } \\
\text { nic }\end{array}$ & $\begin{array}{l}\text { Blue } \\
\text { Green }\end{array}$ & Spreading & Spreading \\
\hline 10 & Nostocsp. & YPR-10 & Benthic & $\begin{array}{l}\text { Light } \\
\text { green }\end{array}$ & Spreading & Spreading \\
\hline
\end{tabular}


Table.3 Morphologically identified cyanobacterial strains and their close match as revealed by BLAST analysis

\begin{tabular}{|c|l|l|l|c|}
\hline $\begin{array}{c}\text { Salt } \\
\mathbf{( \% )}\end{array}$ & \multicolumn{1}{|c|}{ Strain } & \multicolumn{1}{|c|}{$\begin{array}{c}\text { Morphologically } \\
\text { identified genera }\end{array}$} & \multicolumn{1}{|c|}{$\begin{array}{c}\text { Close match based on } \\
\text { 16SrDNA sequence }\end{array}$} & Score (\%) \\
\hline $\mathbf{3}$ & YPR-1 & Anabaena sp. & Anabaena bergii & $98 \%$ \\
\hline $\mathbf{3}$ & YPR-2 & Anabaena sp. & Anabaena oryzae & $97 \%$ \\
\hline $\mathbf{3}$ & YPR-3 & Phormidiumsp. & Phormidium inundatum & $98 \%$ \\
\hline $\mathbf{1}$ & YPR-4 & Westiellopsissp. & Westiellopsis prolifica & $99 \%$ \\
\hline $\mathbf{2}$ & YPR-5 & Westiellopsissp. & Westiellopsis sp. & $97 \%$ \\
\hline $\mathbf{1}$ & YPR-6 & Synechocystissp. & Synechocystis sp & $98 \%$ \\
\hline $\mathbf{3}$ & YPR-7 & Anabaena sp. & Nostoc elgonense TH3S05 & $99 \%$ \\
\hline $\mathbf{1}$ & YPR-8 & Phormidiumsp. & Phormidium priestleyi ANT.LACV5 & $99 \%$ \\
\hline $\mathbf{3}$ & YPR-9 & Nostocsp. & Nostoc punctiforme VB62229 & $95 \%$ \\
\hline $\mathbf{1}$ & YPR-10 & Nostocsp. & Nostoc commune VB516200 & $99 \%$ \\
\hline
\end{tabular}

Table.4 Selected physiological attributes of the cyanobacterial isolates from Rann of Kutch showing mycosporine like amino acids

\begin{tabular}{|c|c|c|c|c|}
\hline Strains & $\begin{array}{c}\text { Dry weight } \\
(\mathbf{m g} / \mathbf{m l})\end{array}$ & $\begin{array}{c}\text { Protein } \\
(\mu \mathrm{gg} / \mathrm{ml})\end{array}$ & $\begin{array}{c}\text { Sugar } \\
(\mu \mathrm{g} / \mathrm{ml})\end{array}$ & $\begin{array}{c}\text { Chlorophyll } \\
(\mu \mathrm{g} / \mathrm{ml})\end{array}$ \\
\hline YPR-1 & $255.62^{\mathrm{fg}}$ & $773.84^{\mathrm{b}}$ & $605.9^{\mathrm{b}}$ & $0.658^{\mathrm{e}}$ \\
\hline YPR-2 & $332.02^{\mathrm{ab}}$ & $949.61^{\mathrm{a}}$ & $563.79^{\mathrm{b}}$ & $2.219^{\mathrm{a}}$ \\
\hline YPR-3 & $316.93^{\mathrm{bc}}$ & $716.64^{\mathrm{b}}$ & $1467.9^{\mathrm{a}}$ & $0.372^{\mathrm{f}}$ \\
\hline YPR-4 & $349.68^{\mathrm{a}}$ & $106.55^{\mathrm{d}}$ & $1377.8^{\mathrm{a}}$ & $1.499^{\mathrm{b}}$ \\
\hline YPR-5 & $259.28^{\mathrm{fg}}$ & $327.54^{\mathrm{c}}$ & $118.89^{\mathrm{b}}$ & $0.276^{\mathrm{f}}$ \\
\hline YPR-6 & $276.94^{\mathrm{ef}}$ & $144.93^{\mathrm{d}}$ & $1363.8^{\mathrm{a}}$ & $0.118^{\mathrm{g}}$ \\
\hline YPR-7 & $307.51^{\mathrm{cd}}$ & $716.64^{\mathrm{b}}$ & $371.90^{\mathrm{b}}$ & $0.778^{\mathrm{d}}$ \\
\hline YPR-8 & $248.48^{\mathrm{g}}$ & $86.33^{\mathrm{d}}$ & $1413.4^{\mathrm{a}}$ & $0.359^{\mathrm{f}}$ \\
\hline YPR-9 & $291.52^{\mathrm{de}}$ & $724.95^{\mathrm{b}}$ & $563.79^{\mathrm{b}}$ & $1.020^{\mathrm{c}}$ \\
\hline YPR10 & $266.97^{\mathrm{fg}}$ & $79.665^{\mathrm{d}}$ & $497.11^{\mathrm{b}}$ & $0.010^{\mathrm{g}}$ \\
\hline
\end{tabular}

Table.5 Selected physiological attributes of the cyanobacterial isolates from Rann of Kutch showing mycosporine like amino acids

\begin{tabular}{|c|c|c|c|c|}
\hline Strains & $\begin{array}{c}\text { Carotenoids } \\
(\mu \mathrm{g} / \mathrm{ml})\end{array}$ & $\begin{array}{c}\text { Phycocyanin } \\
(\mu \mathrm{g} / \mathrm{ml})\end{array}$ & $\begin{array}{c}\text { Allophycocynin } \\
(\mu \mathrm{g} / \mathrm{ml})\end{array}$ & $\begin{array}{c}\text { Phycoerythrin } \\
(\mu \mathrm{mg} / \mathrm{ml})\end{array}$ \\
\hline YPR-1 & $2.421^{\mathrm{bcd}}$ & $6.430^{\mathrm{b}}$ & $0.133^{\mathrm{cd}}$ & $1.592^{\mathrm{ab}}$ \\
\hline YPR-2 & $5.828^{\mathrm{a}}$ & $5.640^{\mathrm{c}}$ & $0.097^{\mathrm{d}}$ & $1.400^{\mathrm{abc}}$ \\
\hline YPR-3 & $1.577^{\mathrm{bcd}}$ & $4.270^{\mathrm{d}}$ & $0.086^{\mathrm{d}}$ & $1.059^{\mathrm{bcd}}$ \\
\hline \hline YPR-4 & $3.28^{\text {abcd }}$ & $1.003^{\mathrm{f}}$ & $0.159^{\mathrm{c}}$ & $0.239^{\mathrm{f}}$ \\
\hline YPR-5 & $3.986^{\mathrm{ab}}$ & $3.630^{\mathrm{d}}$ & $0.156^{\mathrm{c}}$ & $0.894^{\text {cde }}$ \\
\hline YPR- 6 & $0.774^{\mathrm{cd}}$ & $7.746^{\mathrm{a}}$ & $0.027^{\mathrm{e}}$ & $1.930^{\mathrm{a}}$ \\
\hline YPR-7 & $2.484^{\mathrm{bcd}}$ & $1.31^{\mathrm{ef}}$ & $0.226^{\mathrm{b}}$ & $0.311^{\mathrm{ef}}$ \\
\hline YPR-8 & $1.444^{\mathrm{bcd}}$ & $2.016^{\mathrm{e}}$ & $0.120^{\mathrm{cd}}$ & $0.494^{\text {def }}$ \\
\hline YPR-9 & $3.600^{\mathrm{abc}}$ & $8.05^{\mathrm{a}}$ & $0.282^{\mathrm{a}}$ & $1.418^{\mathrm{abc}}$ \\
\hline YPR10 & $0.244^{\mathrm{d}}$ & $7.483^{\mathrm{a}}$ & $0.081^{\mathrm{d}}$ & $1.861^{\mathrm{a}}$ \\
\hline
\end{tabular}


Table.6 Activity of enzymes involved in nitrogen metabolism in the cyanobacterial isolates from Rann of Kutch

\begin{tabular}{|c|c|c|c|}
\hline Strains & $\begin{array}{c}\text { ARA } \\
(\boldsymbol{\mu ~ m o l / m g ~ c h l / h})\end{array}$ & $\begin{array}{c}\text { NR } \\
\left(\boldsymbol{\mu ~ m o l} / \mathbf{m g ~ p r o t e i n}^{-h}\right)\end{array}$ & $\begin{array}{c}\text { GS } \\
(\boldsymbol{\mu} \text { mol/mg protein })\end{array}$ \\
\hline YPR-1 & $17.949^{\mathrm{b}}$ & $16.559^{\mathrm{cd}}$ & $181.248^{\mathrm{bc}}$ \\
\hline YPR-2 & $4.277^{\mathrm{e}}$ & $18.421^{\mathrm{bc}}$ & $107.372^{\mathrm{e}}$ \\
\hline YPR-3 & ------ & $28.914^{\mathrm{b}}$ & $135.865^{\mathrm{cd}}$ \\
\hline YPR-4 & $6.29^{\mathrm{e}}$ & $94.914^{\mathrm{a}}$ & $186.069^{\mathrm{bc}}$ \\
\hline YPR-5 & $35.28^{\mathrm{a}}$ & $12.913^{\mathrm{cd}}$ & $204.143^{\mathrm{abc}}$ \\
\hline YPR-6 & ------- & $14.801^{\mathrm{cd}}$ & $130.496^{\mathrm{de}}$ \\
\hline YPR-7 & $14.42^{\mathrm{c}}$ & $15.379^{\mathrm{cd}}$ & $166.12^{\mathrm{cd}}$ \\
\hline YPR-8 & ------ & $5.206^{\mathrm{d}}$ & $211.625^{\mathrm{ab}}$ \\
\hline YPR-9 & $8.97^{\mathrm{d}}$ & $22.82^{\mathrm{bc}}$ & $182.9389^{\mathrm{bc}}$ \\
\hline YPR-10 & $8.556^{\mathrm{d}}$ & $91.303^{\mathrm{a}}$ & $232.401^{\mathrm{a}}$ \\
\hline
\end{tabular}

$\mathrm{ARA}=$ Acetylene reduction activity, $\mathrm{NR}=$ Nitrate reductase activity and GS= Glutamine synthetase activity

Plate.1 Isolated genomic DNA by Dneasy tissue kit manufacturer's protocol with certain modifications

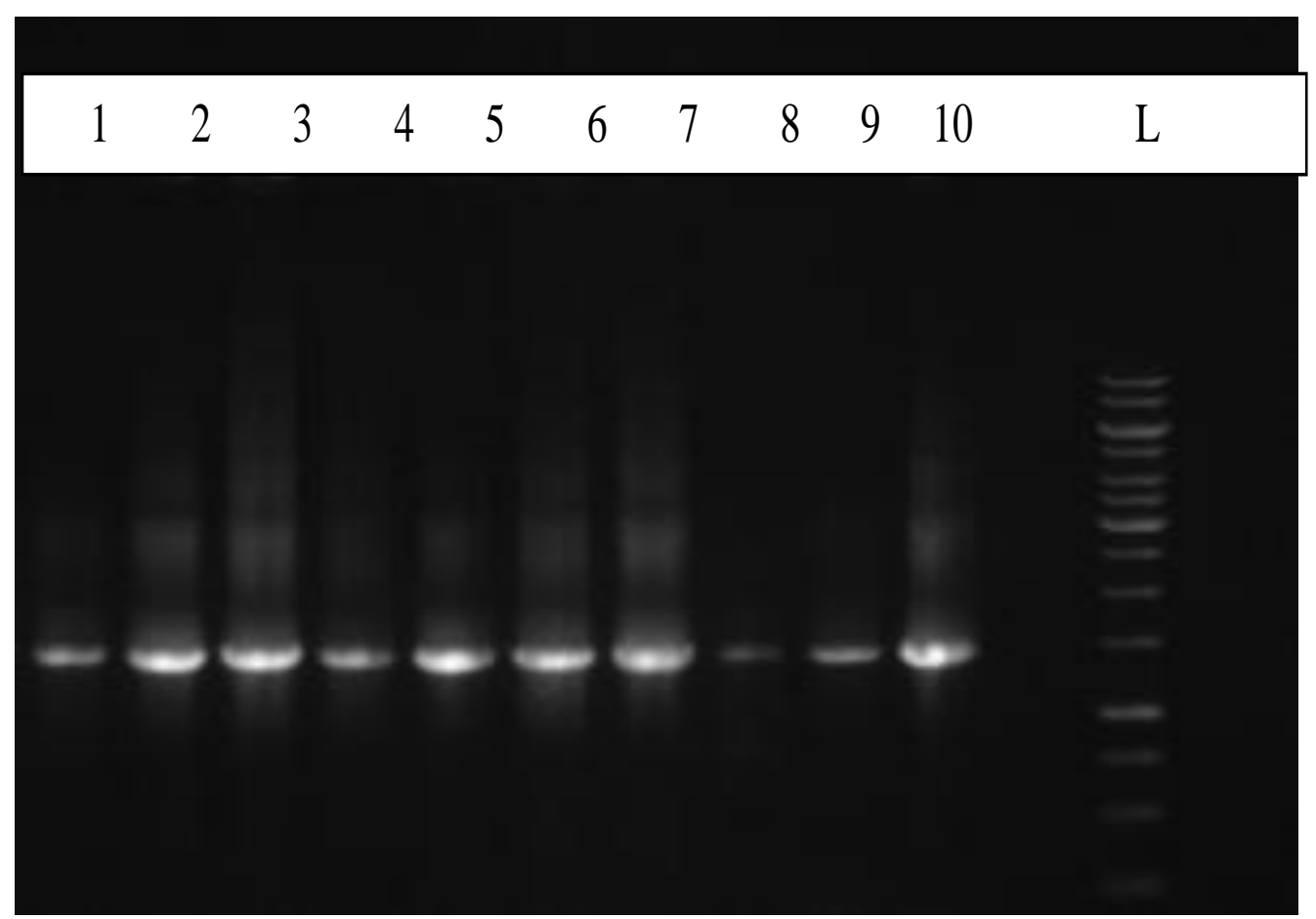

$\mathrm{L}=1 \mathrm{~Kb}$ ladder

1.YPR-1, 2.YPR-2, 3.YPR-3, 4.YPR-4, 5.YPR-5, 6.YPR-6, 7.YPR-7, 8.YPR-8, 9.YPR-9, 10.YPR-10 
Plate.2 16S rDNA amplified product in cyanobacterial isolates from Rann of Kutch

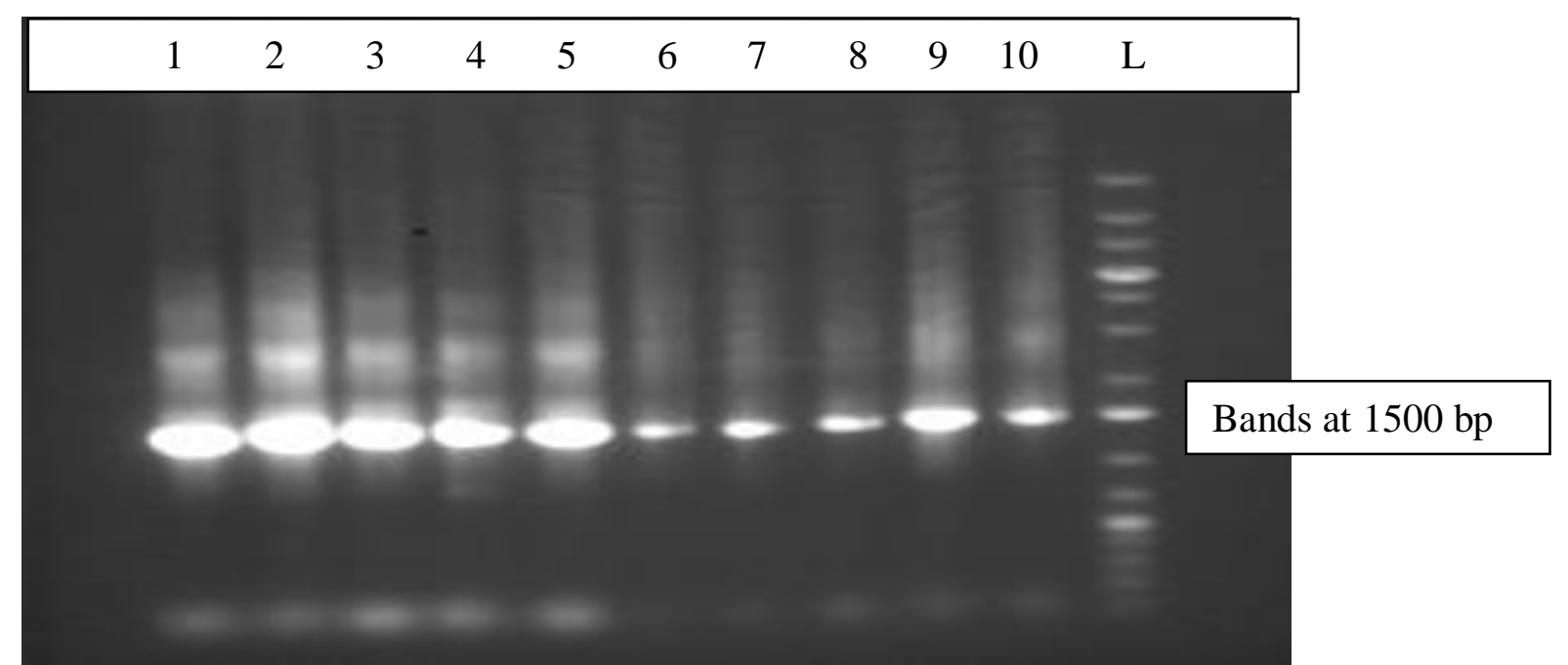

1.YPR-1, 2.YPR-2, 3.YPR-3, 4.YPR-4, 5.YPR-5, 6.YPR-6, 7.YPR-7, 8.YPR-8, 9.YPR-9, 10.YPR-10, L= ladder

The nitrogenase enzyme activity was found to be in the range of 4.277 to $35.28 \mu$ moles $/ \mathrm{mg}$ chl/h. The strain YPR-5 showed highest ARA activity as compared to YPR-2 which showed low levels of activity.

Microscopic observations of the samples collected from Rann of Kutch revealed the presence of several cyanobacterial isolates and the identified forms belonged to Anabaena, Nostoc, Westiellopsis and Phormidiu. Although, there are several reports on the occurrence of cyanobacteria in saline soils the type of cyanobacteria found in such saline soils are different (Ali and Sandhu, 1972; Kaushik, 1989; Shah et al., 2000). In less saline conditions, the heterocystous cyanobacteria have advantage over non heterocystous cyanobacteria due to the presence of glycolipid envelope of the heterocyst (Stal, 1991). According to (Srivastav et al., 2009) low salinity favours heterocystous cyanobacteria where as high salinity supports growth of non-heterocystous genera. It is difficult to characterize the cyanobacteria on the basis of observing structures such as hormogonia, heterocysts and akinites (Nubel et al., 2000) and hence the molecular identification is important. In the present study to support the morphological identification of the cyanobacteria, 16SrRNA gene amplification was carried out. BLAST analysis was employed to establish homology in terms of percentage similarity and revealed that the identified cyanobacteria had close similarity with cultured cyanobacteria. (Rudi et al., 1997) used 16S rRNA for individual strain characterization and identification of cyanobacteria. Similar observations were also made by (Srivastav et al., 2009).

The variation in the growth rate of several species of Anabaena collected from a geographical habitat was observed by (Meeks et al., 1983). Ambient physiological conditions also play a role in the growth and cellular constituents. Biochemical constituents of cyanobacteria depend upon the nature of strains, physiological conditions and the environment (Maslova et al., 2004; Rosales et al., 2005). (Mekonnen et al., 2002) reported variation in chlorophyll content within the genus as well as species of cyanobacteria characterized. Significant variation with respect to the carotenoids and phycobiliproteins was also observed in the study. Anabaena strains isolated from 
different geographical locations showed significant differences in the phycobiliprotein content as shown by (Prasanna et al., 2006). The chlorophyll and carotenoids in the organisms is related to the physiological competence of the cells in case of cyanobacteria isolated from hyper-saline environments. Significant differences in the sugar content was observed and those isolates growing at high concentrations of salinity showed very high sugar content as compared to their counterparts growing at low levels of salinity. Cyanobacteria exposed to stress conditions respond by the synthesis of osmotically active compounds such as sugars to counter the salinity stress (Ponti et al., 2007). Increase in the sugar content observed could therefore, be related to the survival of the organisms at higher concentrations of salt. (Asthana et al., 2008) observed enhanced trehalose content in the cyanobacterium Anabaena 7120 under salinity stress.

Significant variation with respect to the enzymes involved in nitrogen metabolism such as nitrate reductase, glutamine synthetase and nitrogenase was observed. Increase in the nitrate reductase activity under salinity is due to increased nitrogen demand of the cyanobacteria (Rai and Abraham, 1993). Difference in the nitrate reductase and glutamine synthetase activity has been reported in cyanobacterial strains isolated from extreme Antarctic environment by (Pandey et al., 2004). The sensitivity of the nitrogen fixing makes it difficult for cyanobacteria to survive in extreme habitats (Reed and Stewart, 1985). (Moisander et al., 2002) observed decreased nitrogenase activity in cyanobacterial strains isolated from an estuarine water. The study of these enzymes is important keeping in view of the potential of cyanobacteria as bioinoculants. (Prasanna et al., 2006) also studied these parameters from Anabaena isolates collected from different biogeographical habitats.
The studies therefore showed that several cyanobacterial strains isolated from Runn of Kutch exhibited distinct patterns of growth, cellular constituents and nitrogen fixation. The responses are adaptive in nature and help the organism to grow and survive under inhospitable habitats. Further detailed analysis needs to be conducted to decipher the exact nature of tolerance mechanisms studies using molecular tools.

\section{References}

Ali S and Sandhu GR (1972). Blue-green algae of the saline soils of the Punjab. Oikos 23: 268-272.

Asthana RK, Nigam S, Maurya A, Kayastha AM and Singh SP (2008). Trehaloseproducing enzymes MTSase and MTHase in Anabaena 7120 under $\mathrm{NaCl}$ Stress. Curr. Microbio. 156: 429-435.

Bennett A and Bogorad L (1973). Complemenary chromatic adaptation in a filamentous blue-green alga. $J$ Cell Biol58: 419-435.

Burja AM, Banaigs B, About-Mansour E, Burgess JG and Wright PC (2001). Marine cyanobacteria a prolific source of natural products. Tetrahedran 57: 9347-9377.

Desikachary TV (1959). Cyanophyta, Indian Council of Agricultural Research, New Delhi.

Gröniger A and Hader D-P (2000). Stability of mycosporine-like amino acids. Recent Res Devel Photochem Photobiol. 4:247-252.

Herrero A and Flores E (2008). The Cyanobacteria: Molecular Biology, Genomics and Evolution. Caister, Academic Press.

Herrero A, Flores E and Guerrero MG (1981). Regulation of nitrate reducatase levels in the cyanobacteria Anacystis nidulans strain 6719. J Bacteriol. 145: 175-180. 
Jensen A (1978). Chlorophylls and Carotenoids, In: Hellebust JA, Craige JS (eds), Phycological Methods: physiological and biochemical methods, Cambridge University Press, Cambridge, pp 59-70.

Kaushik BD (1989). Reclamative potential of cyanobacteria in salt-affected soils. Phykos. 28:101-109.

Lowry $\mathrm{OH}$, Rosebrough NJ, Farr AL and Randall RJ (1951). Protein measurement with the Folin-Phenol reagents. J Biol. Chem. 193: 265-275.

Lyra C, Hantula J, Vanio E, Rapala J, Rouhiainen L and Sivonen K (1997). Characterization of cyanobacteria by SDS-PAGE of whole cell proteins and PCR/RFLP of the $16 \mathrm{~S} \mathrm{r}$ RNA gene. Arch Microbiol 168: 176-184.

Maslova IP, Mouradyan EA, Lapina SS, Klyachko-Gurvich GL and Los DA (2004). Lipid fatty acid composition and thermophilicity of cyanobacteria. Russ $J$ Plant Physiol51: 353 - 360.

McKinney (1941). Absorption of light by chlorophyll solutions. J BiolChem 140: 315-332.

Meeks JC, Wycoff KL, Chapman JS and Enderlln CS (1983). Regulation of expression of nitrate and dinitrogen assimilation by Anabaena species. Appl Environ Microbiol45: 1351-1359.

Mekonnen AE, Prasanna R and Kaushik BD (2002). Response of Anabaena species to different nitrogen sources. ActaBiolHungarica53: 367-380.

Moisander PH, Hench JL and Kononen K (2002). Small-scale shear effects on heterocystous cyanobacteria. Limnol Oceanogr. 47:108-119.

Nubel U, Garcia-Pichel F, Clavero E and Muyzer G (2000). Matching molecular diversity and ecophysiology of benthic cyanobacteria and diatoms in communities along a salinity gradient.Environ Microbiol2: 217-226.
Oren A (2000). Salts and Brine. The Ecology of Cyanobacteria. Kluwer Academic Publishers. Netherlands, pp. 281-306.

Pandey KD, Shukla SP and Shukla PN (2004). Cyanobacteria in Antarctica: Ecology, physiology and cold adaptation. Cell MolBiol. 50(5):575584.

Ponti M, Pinna M, Vadrucci MR and Orfanidis S (2007). Biotic indices of transitional ecosystem health. Technical report of twreferenceneteuinterregiiib project 3B073 Management and Sustainable Development of Protected Transitional Waters. E-content. pp. 281306.

Prasanna R, Kumar R, Sood A, Prasanna BM and Singh PK (2006). Morphological, physiochemical and molecular characterization of Anabaena strains. Microbiol Res 161: 187-202.

Rai AK and Abraham G (1993). Salinity tolerance and growth analysis of the cyanobacterium Anabaena doliolum. Bull Envirn Contam Toxicol. 51:724731.

Reed RH and Stewart WDP (1985). Osmotic adjustment and organic solute accumulation in unicellular cyanobacteria from freshwater and marine habitats. Mar Bio.l 88: 1-9.

Rosales N, Ortega J, Mora R and Morales E (2005). Influence of salinity on the growth and biochemical composition of the cyanobacterium Synechococcus sp. Cienc Marin 31: 349 - 355.

Rudi K, Skulberg OM, Larsen F and Jakobsen KS (1997). Strain characterization and classification of oxyphotobacteria in clone cultures on the basis of 16S rRNA sequence from the variable region V6, V7 and V8. Appl Environ Microbiol 63(7): 2593-2599

Shah V, Ray A, Garg N, Madamwar D (2000). Characterization of the extracellular polysaccharide produced 
by a marine cyanobacterium Cyanothece sp. ATCC 51142, and its exploitation toward metal removal from solutions. CurrMicrobiol. 40: 274-278.

Shapiro BM, and Stadtman ER. (1970). Glutamine synthetase (E. coli).Methods Enzymol. 17: 910-922.

Sorokin C (1973). Dry weight packed cell volume and optical density. In: Stein JR (ed), Handbook of Phycological Methods. Culture Methods and Growth Measurements. Cambridge University Press, Cambridge, pp. 321-343.

Spiro RA (1966). Analysis of sugars found in glycoproteins. Methods Enzymol 8: 326.

Srivastava A, Bhargava P, Kumar A, Rai LC and Neilan B (2009). Molecular characterization and the effect of salinity on cyanobacterial diversity in the rice fields of Eastern Uttar Pradesh, India. Saline Systems. 5: 1-17.

Srivastava A, Bhargava P, Kumar A, Rai LC and Neilan B (2009). Molecular characterization and the effect of salinity on cyanobacterial diversity in the rice fields of Eastern Uttar Pradesh, India. Saline Systems 5: 1-17.

Stal LJ (1991). The metabolic versatility of the mat-building cyanobacteria Microcoleus chthonoplastes and Oscillatoria limosa and its ecological significance. Algol Studies. 64: 453467.

Stanier RY, Kunisawa R, Mendel M and Cohen-Bazire (1971) Purification and properties of unicellular blue-green algae (Chroococcales). Bacteriol Rev 35: 171-205.

Stewart WDP, Fitzgerald GP and Burris RH (1968). Acetylene reduction by nitrogen fixing blue green algae. Arch. Microbiol. 62 (4): 336-348.

Weisburg WG, Barns SM, Pelletier DA and Lane DJ (1991). 16S ribosomal DNA amplification for phylogenetic study. $J$ Bacteriol 37: 463-464.

Whitton BA and Potts M (2000). Introduction to the Cyanobacteria. In: The Ecology of Cyanobacteria: Their Diversity in Time and Space, Whitton BA, Potts M (eds) Dordrecht, Kluwer Academic Press, pp. 1-11.

\section{How to cite this article:}

Yattapu Prasad Reddy, Ravindra Kumar Yadav and Abraham G. 2018. Characterization of Cyanobacterial Isolates from Rann of Kutch for Salinity Tolerance. Int.J.Curr.Microbiol.App.Sci. 7(06): 994-1003. doi: https://doi.org/10.20546/ijcmas.2018.706.117 